\title{
Kidney aminopeptidase activities are related to renal damage in experimental breast cancer
}

\author{
José Manuel Martínez-Martos ${ }^{1}$,María del Pilar Carrera ${ }^{1,2}$, Rafael Sánchez-Agesta ${ }^{1,3}$, María Jesús García ${ }^{1,4}$ and María Jesús Ramírez-Expósito $^{1 *}$ \\ ${ }^{1}$ Experimental and Clinical Physiopathology Research Group CTS-1039; School of Health Sciences, Department of Health Sciences, University of Jaén, Campus \\ Universitario Las Lagunillas, Jaén, Spain \\ ${ }^{2}$ Department of Nursing, University of Córdoba, Córdoba, Spain \\ ${ }^{3}$ Unit of Clinical Biochemistry, Complejo Hospitalario de Jaén, Jaén, Spain \\ ${ }^{4}$ Laboratorio Central de Sanidad Animal, Santafé, Granada, Spain
}

\begin{abstract}
Background: Several peptides act in kidney, being the angiotensins of the renin-angiotensin-aldosterone system the best described. However, other lesser known include vasopressin, oxytocin, gonadotrophin releasing hormone or tyrotrophin releasing homone, with renal functions mainly unresolved. We had described changes in several circulating and tissue aminopeptidase activities both in women and rats with breast cancer. These changes have been involved not only in breast disease, but also in other functions of concomintantly affected tissues.
\end{abstract}

Aim of the study: To analyze renal functions mediated by biologically active peptides in animals with breast cancer through the analysis of their regulatory aminopeptidases.

Methods: Soluble and membrane-bound forms of aminopeptidase N, aminopeptidase B, aspartyl aminopeptidase, aminopeptidase A, insulin-regulated aminopeptidase, cystinyl aminopeptidase and pyroglutamyl aminopeptidase specific activities are measured in renal cortex and medulla of rats with mammary tumors induced by $\mathrm{N}$-methyl-N-nitrosourea (NMU). Plasma and urine electrolytes (sodium, potassium, chloride, calcium, phosphorus), non-protein nitrogenous compounds (urea, creatinine, uric acid), albumin and total protein, are measured as markers of renal function.

Results: We found that rats with breast cancer show hypo- proteinemia and albuminemia, proteinuria and albuminuria, but no other changes in plasma and urine chemistry parameters. Also, changes in soluble and membrane-bound aminopeptidases are found in renal cortex and medulla.

Conclusions: Although the mechanism by which breast cancer promotes renal damage remains unknown, we suggest that early events during the illnes alter the funtions mediated by certain bioactive peptides and could make the kidney more sensitive to future damage.

\section{Introduction}

Aminopeptidases are proteolytic regulatory enzymes that play critical roles in the regulation of several peptide hormones such as angiotensins, oxytocin, vasopressin, gonadotrophin releasing hormone (GnRH) or tyrotrophin releasing hormone (TRH), among others. Our laboratory has described modifications in several circulating and tissue aminopeptidase activities in breast cancer, both in women [1-4] and in the animal model of breast cancer induced by $\mathrm{N}$-methyl nitrosourea (NMU) [5-10]. These activities could reflect the status of their peptides substrates, which may be implied in the initiation, promotion and/or progresion of this disease, or reflect concomitant changes in several functions regulated by them in other affected tissues. In this way, altered functions have been described in the pineal gland [11], the ovary [12] and the hypothalamus-pituitary tyroid axis $[13,14]$.

In kidney, several aminopeptidases also regulate important physiological functions, such as those mediated by the well known renin-angiotensin-aldosterone system (RAAS), but also by other less known peptide hormones such as oxytocin, vasopressin, GnRH or TRH.

Regarding the RAAS, all their components are present within the kidney, including renin, renin receptor, angiotensinogen, angiotensins, angiotensin receptors and aldosterone synthase mRNA and protein, which are present in close proximity to the renal vasculature and tubules [15]. This system is a well known regulator of blood pressure and hydroelectrolytic balance [16], being angiotensin peptides their main effectors, which are formed via the activity of several aminopeptidases, also called angiotensinases [17]. Angiotensinases are peptidases that generate active or inactive angiotensin peptides that alter the ratios between their bioactive forms. To this category belong aspartyl aminopeptidase (ASAP) and aminopeptidase A (APA) [18], aminopeptidase $\mathrm{B}(\mathrm{APB})$ and aminopeptidase $\mathrm{N}(\mathrm{APN})$, involved in the removal of the first amino acid of the peptide chain of AngII for the formation of AngIII and AngIV. Thus, AngII degradation begins with the action of APA, which removes the N-terminal Asp to produce AngIII. AngIII is further converted to AngIV by APN or APB. AngII and AngIII mediates their action through AT1 and AT2 receptor subtypes

*Correspondence to: María Jesús Ramírez-Expósito, School of Health Sciences, Department of Health Sciences, University of Jaén, Campus Universitario Las Lagunillas, E-23071, Jaén, Spain

Key words: Aspartyl aminopeptidase, insulin-regulated aminopeptidase, pyroglutamyl aminopeptidase, proteinuria, albuminuria, nephrotoxicity

Received: March 27, 2018; Accepted: April 14, 2018; Published: April 17, 2018 
[19,20], whereas AngIV seem to acts at the AT4 receptor subtype [21], which has been identified as the enzyme leucine aminopeptidase, also called insulin-regulated aminopeptidase (IRAP) or more recently, as the hepatocyte growth factor (HGF)/c-Met receptor system [22]. On the other hand, tissue carboxypeptidases and other proteolytic enzymes (such as trypsin, chymotrypsin, pepsin and others) contribute to the inactivation of the active forms of angiotensins, transforming them into inactive fragments and amino acid constituents [21,23]. A separate pathway for the synthesis of AngIII, independent of AngII formation, is via the nonapeptide [des-Asp1]AngI, formed from AngI by ASAP [24]. This nonapeptide is converted directly to AngIII via ACE.

By other hand, cystinyl aminopeptidase activity, also called vasopressinase or oxytocinase, hydrolyzes amino-terminal cysteine residues of various peptides and polypeptides including oxytocin, vasopressin and opioid peptides [25,26]. Cystinyl aminopeptidase is a protein involved in a large variety of functions including parturition, milk ejection, blood pressure, water balance, local blood flows, glucose homeostasis, and cognitive functions [27-29]. In kidney, a close relationship between CysAP and the RAAS has been also described [27], and the enzyme has been immunolocalized in the renal tubules [28].

In kidney it has been also located binding points for $\mathrm{GnRH}$ related to estrogens and progesterone receptors [30]. Furthermore, Heber, et al. [31] had described down affinity specific points for the GnRH in renal cortex. Also, thyroid hormones influence renal development, kidney hemodynamic, glomerular filtration rate and sodium and water homeostasis [32]. The enzyme pyroglutamyl aminopeptidase (PAP) is involved in the inactivation of GnRH and TRH [33-35]. PAP enzyme has been also described as a renal damage marker [36], together with IRAP [37].

In this context, the aim of the present work was to analyze several aminopeptidase activities in their soluble and membrane-bound forms in renal cortex and medulla of rats with breast cancer induced by $\mathrm{N}$-methyl nitrosourea (NMU) to analyze if this pathology could alter renal functions in which their corresponding peptide-hormone substrates may be involved.

\section{Materials and methods}

\section{Animals and treatment}

Forty female virgin Wistar rats $(164.7 \pm 4.7 \mathrm{~g}$ body weight $)$ were used in this work. The animals were provided from the animal house care of the University of Jaén, and maintained in an environment controlled under constant temperature $\left(25^{\circ} \mathrm{C}\right)$ with a $12 \mathrm{~h}$ light / $12 \mathrm{~h}$ dark cycle. Animals were allowed access to water and food ad libitum. The experimental procedures for animal use and care were in accordance with the European Community Council directive (2010/63/ $\mathrm{EU}$ ) and approved by the ethical committee of the University of Jaén. The rats were randomly divided into two groups. One group were injected intraperitoneally with three doses of $50 \mathrm{mg} / \mathrm{Kg}$ body weight of NMU dissolved in distilled water $(10 \mathrm{mg} / \mathrm{ml})$ at 50,80 and 110 days after birth, as previously described $[9,10]$. All rats were at estrus at the first NMU injection, verified by daily vaginal smears. Animals treated with NMU but which did not develop mammary tumors were also considered for analysis of the putative concomitant effects of NMU. Control group received the vehicle only.

\section{Sample preparation}

After 122 days of first NMU injection, animals were sacrificed under equithesin anesthesia $(2 \mathrm{ml} / \mathrm{kg}$ body weight) and their right kidney removed. To obtain soluble fraction, tissue samples were homogenized in 10 volumes of $10 \mathrm{mM} \mathrm{HCl}$-Tris buffer ( $\mathrm{pH}$ 7.4) and ultracentrifuged at $100,000 \mathrm{xg}$ for $30 \mathrm{~min}\left(4^{\circ} \mathrm{C}\right)$. The supernatants were used to measure soluble enzymatic activity and protein content in triplicate. To solubilize membrane proteins, the pellets were homogenized again in HCl-Tris buffer ( $\mathrm{pH} 7.4$ ) plus $1 \%$ Triton X-100. After centrifugation $\left(100,000 \mathrm{xg}, 30 \mathrm{~min}, 4^{\circ} \mathrm{C}\right)$, the supernatants was used to determinate solubilized membrane-bound activity and proteins in triplicate.

\section{Aminopeptidase activity assays}

Aspartyl aminopeptidase (ASAP) activity assay: ASAP was measured fluorometrically using aspartyl- $B$-naphthylamide (AspNNap) as the substrate. Briefly, ten microlitres of each sample was incubated in triplicate for $30 \mathrm{~min}$ at $37^{\circ} \mathrm{C}$ with 100 microlitres of the substrate solution containing $100 \mu \mathrm{M}$ AspNNap, $1.3 \mu \mathrm{M}$ ethylenediaminetetraacetic acid (EDTA) and $2 \mathrm{mM} \mathrm{MnCl}_{2}$ in $50 \mathrm{mM}$ of phosphate buffer, $\mathrm{pH}$ 7.4.

\section{Aminopeptidase A (APA) activity assay}

APA activity was measured in the same way using glutamylß-naphthylamide (GluNNap) as the substrate. Ten microlitres of each sample was incubated in triplicate for $30 \mathrm{~min}$ at $37^{\circ} \mathrm{C}$ with 100 microlitres of the substrate solution containing $100 \mu \mathrm{M}$ GluNNap, 0.65 $\mathrm{mM}$ dithiothreitol (DTT) and $50 \mathrm{mM} \mathrm{CaCl}_{2}$ in $50 \mathrm{mM}$ of phosphate buffer, $\mathrm{pH}$ 7.4.

\section{Aminopeptidase N (APN) activity assay}

APN was measured fluorometrically using alanyl- $B$-naphthylamide (AlaNNap) as substrate. Ten microlitres of each sample were incubated by triplicate for 30 minutes at $37^{\circ} \mathrm{C}$ with $100 \mu \mathrm{L}$ of the substrate solution containing $100 \mu \mathrm{M}$ of AlaNNap and $0.65 \mathrm{mM}$ dithiothreitol (DTT) in $50 \mathrm{mM}$ phosphate buffer, $\mathrm{pH} 7.4$.

\section{Aminopeptidase B (APB) activity assay}

APB was measured fluorometrically using arginyl- $ß$-naphthylamide (ArgNNap) as substrate. Ten microlitres of each sample were incubated by triplicate for 30 minutes at $37^{\circ} \mathrm{C}$ with $100 \mu \mathrm{L}$ of the substrate solution containing $100 \mu \mathrm{M}$ of ArgNNap and $0.65 \mathrm{mM}$ dithiothreitol (DTT) in $50 \mathrm{mM}$ phosphate buffer, $\mathrm{pH}$ 7.4.

\section{Insulin-regulated aminopeptidase (IRAP) activity assay}

IRAP activity was measured fluorometrically using leucyl-ßnaphthylamide (LeuNNap) as substrate. Ten microlitres of each sample were incubated by triplicate for 30 minutes at $37^{\circ} \mathrm{C}$ with $100 \mu \mathrm{L}$ of the substrate solution containing $100 \mu \mathrm{M}$ of LeuNNap and $0.65 \mathrm{mM}$ dithiothreitol (DTT) in $50 \mathrm{mM}$ phosphate buffer, $\mathrm{pH}$ 7.4.

\section{Cystinyl aminopeptidase (CysAP) activity Assay}

CysAP activity was measured fluorometrically using cystinyl-ßnaphthylamide (CysNNap) as the substrate. Ten microlitres of each sample were incubated by triplicate for $30 \mathrm{~min}$ at $37^{\circ} \mathrm{C}$ with $100 \mu \mathrm{L}$ of the substrate solution containing $100 \mu \mathrm{M}$ CysNNap and $0.65 \mathrm{mM}$ dithiothreitol (DTT) in $50 \mathrm{mM}$ of phosphate buffer, pH 6.0.

\section{Pyroglutamyl aminopeptidase (PAP) Activity Assay}

PAP activity was measured fluorometrically using pyroglutamyl- $\beta$ naphthylamide (pGLUNNap) as the substrate. Ten microlitres of each sample were incubated by triplicate for 30 minutes at $37^{\circ} \mathrm{C}$ with 100 $\mu \mathrm{L}$ of the substrate solution containing $100 \mu \mathrm{M}$ of pGLUNNap, 0.65 $\mathrm{mM}$ dithiothreitol (DTT) and $1.3 \mu \mathrm{M}$ ethylenediaminetetraacetic acid (EDTA) in $50 \mathrm{mM}$ of phosphate buffer, pH 7.4. 
All the reactions were stopped by adding $100 \mu \mathrm{L}$ of $0.1 \mathrm{M}$ acetate buffer, $\mathrm{pH}$ 4.2. The amount of $B$ naphthylamine released as the result of the enzymatic activities was measured fluorometrically at $412 \mathrm{~nm}$ emission wavelength with and excitation wavelength of $345 \mathrm{~nm}$. Proteins were quantified also in triplicate by the method of Bradford, using bovine serum albumin (BSA) as standard. Specific enzyme activities were expressed as picomoles of the corresponding aminoacyl- $\beta$-naphthylamide hydrolyzed per min per $\mathrm{mg}$ of protein, by using a standard curve prepared with the latter compound under corresponding assay conditions.

\section{Blood and urine chemistry measurements}

Blood and urine chemistry measurements were performed as previously described [38]. Briefly, electrolytes (sodium, potassium and chloride), calcium and phosphorus were assayed using selective ion electrodes. Results are expressed in $\mathrm{mEq} / \mathrm{L}$; calcium and phosphorus were assayed by colorimetric methods. Results are expressed in $\mathrm{mg} /$ dL. The non-protein nitrogenous compounds, uric acid, urea and creatinine were assessed using commercial kits. Results are expressed in $\mathrm{mg} / \mathrm{dL}$. The albumin content was determined by a colorimetric method using a commercial kit. Results are expressed in $\mathrm{g} / \mathrm{dL}$ for plasma and in $\mathrm{mg} / \mathrm{dL}$ for urine. All kits were obtained from Boehringer Mannheim, to be used with the automated Roche-Hitachi 917 system. Total protein was determined by the colorimetric method of Bradford. Results are expressed in $\mathrm{g} / \mathrm{dL}$ for plasma and in $\mathrm{mg} / \mathrm{dL}$ for urine.

\section{Statistical analysis}

To analyze the differences between groups, we used one way analysis of variance (ANOVA) plus Dunnett post-hoc test, using IBM SPSS V.19 software. All comparisons with P values below 0.05 were considered significant.

\section{Results}

Figure 1 shows soluble and membrane-bound aminopeptidase specific activities of the RAAS in the renal cortex of controls and NMU treated rats with or without mammary tumors. No statistical differences were observed between groups either in soluble or membrane-bound fractions on APN (Figure 1A), APB (Figure 1B), ASAP (Figure 1C) or APA (Figure 1D) activities. IRAP (Figure 2A) and CysAP (Figure $2 B$ ) activities were not also modified either in soluble or membranebound fractions in renal cortex of NMU-treated rats with or without mammary tumors. On the contrary, we found a highly significant decrease $(\mathrm{P}<0.001)$ by $51 \%$ in PAP activity in soluble fraction of rats with $\mathrm{NMU}$-induced mammary tumors when compared with the control group or NMU-treated rats without tumors (Figure 2C). However, no changes were found in PAP activity in membrane-bound fraction.

Figure 3 shows soluble and membrane-bound aminopeptidase specific activities of the RAAS in the renal medulla of controls and NMU treated rats with or without mammary tumors. No significant differences were found between groups either in soluble or membranebound fractions on APN (Figure 3A), APB (Figure 3B) and APA (Figure 3D). On the contrary, a highly significant increase $(\mathrm{P}<0.001)$ by $115 \%$ were found in ASAP activity (Figure 3C) in soluble fraction of rats with NMU-induced mammary tumors when compared with the control group or NMU-treated rats without tumors, whereas no changes were found in membrane-bound fraction. Specific IRAP activity in renal medulla is shown in Figure 4A. We found a significant $(\mathrm{P}<0.05)$ decrease $(35 \%)$ in this specific activity in soluble fraction of rats with NMU-induced mammary tumors when compared with the control group or NMU-treated rats without tumors. On the contrary, membrane-bound specific IRAP activity significantly increased

\section{Renal Cortex}
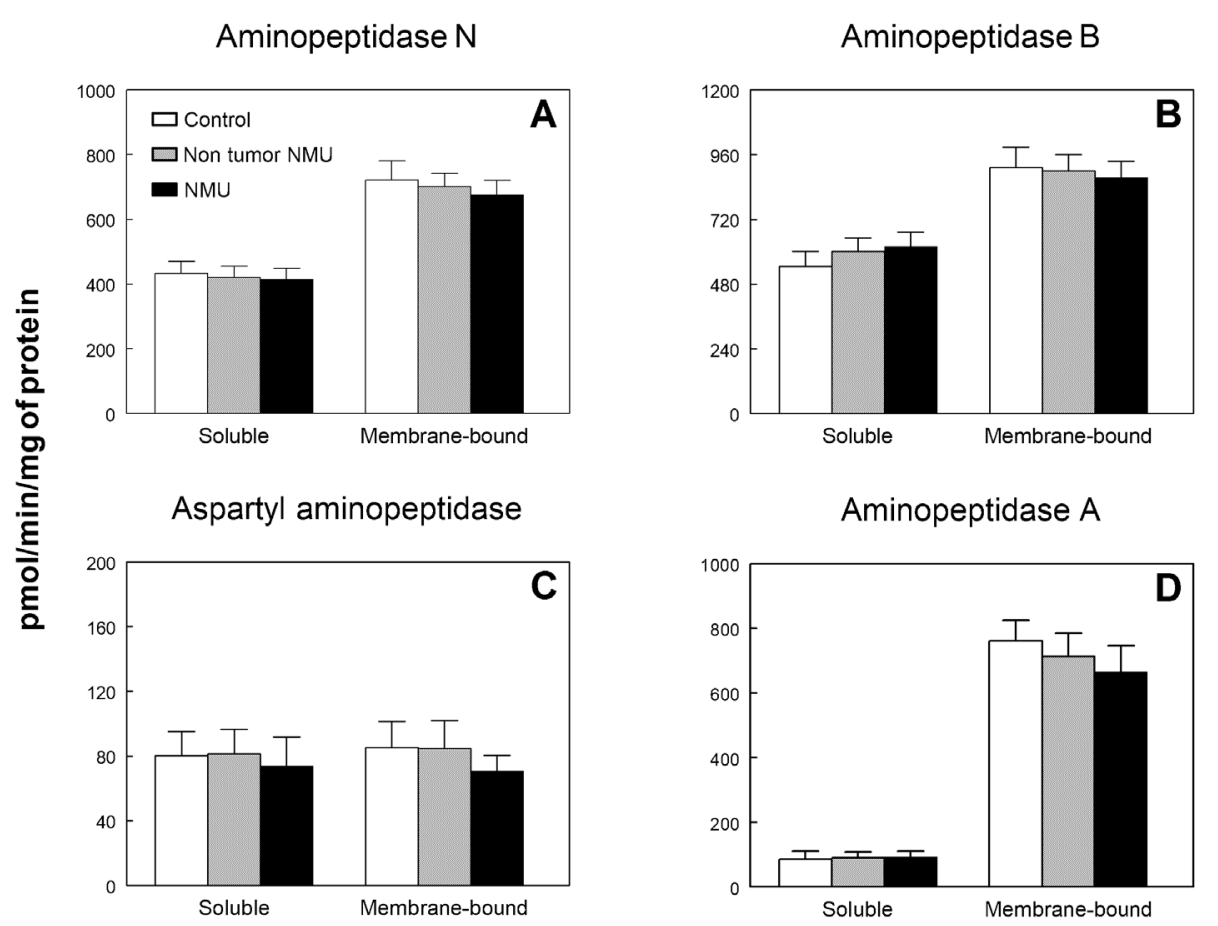

Figure 1. Soluble and membrane bound (A) aminopeptidase N, (B) aminopeptidase B, (C) aspartyl aminopeptidase and (D) aminopeptidase A specific activities in renal cortex of control animals and animals treated with N-methyl-N-nitrosourea (NMU) which developed or not mammary tumors. Results are expressed as picomoles of the corresponding aminoacylß-naphthylamide hydrolyzed per min and per $\mathrm{mg}$ of protein (Mean \pm SEM). 


\section{Renal Cortex}

\section{Insulin-regulated Aminopeptidase}

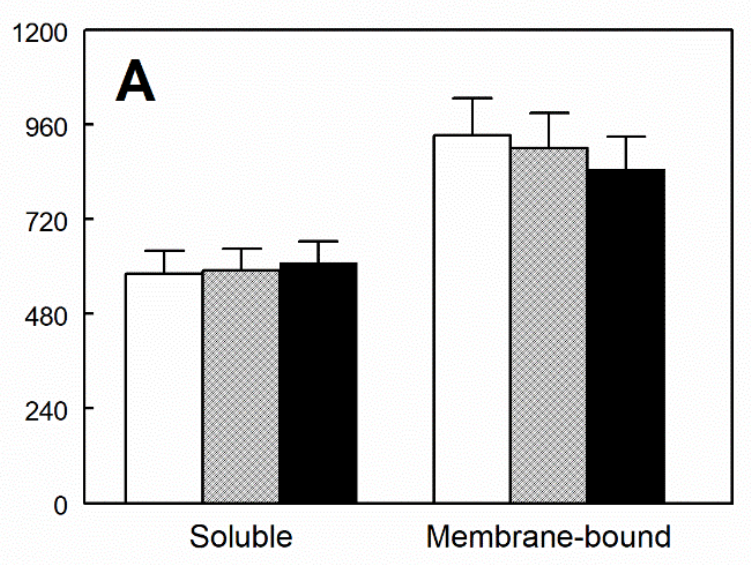

Cystinyl aminopeptidase
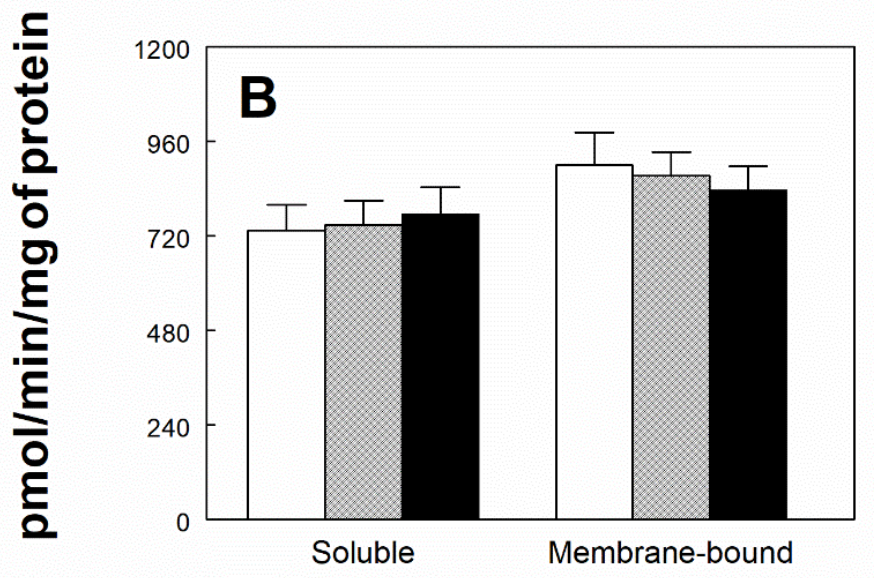

\section{Pyroglutamyl aminopeptidase}

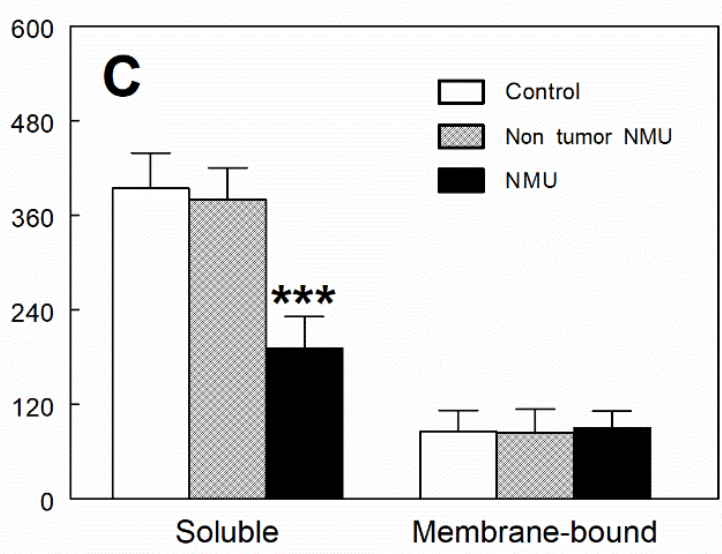

Figure 2. Soluble and membrane bound (A) insulin-regulated aminopeptidase, (B) cystinyl aminopeptidase and (C) pyroglutamyl aminopeptidase specific activities in renal cortex of control animals and animals treated with N-methyl-N-nitrosourea (NMU) which developed or not mammary tumors. Results are expressed as picomoles of the corresponding aminoacyl- $\beta$-naphthylamide hydrolyzed per min and per mg of protein (Mean $\pm \mathrm{SEM}$; $* * * \mathrm{P}<0.001)$.
( $\mathrm{P}>0.001)$ by $118 \%$ in renal medulla of rats with NMU-induced mammary tumors when compared with the control group or NMUtreated rats without tumors (Figure 4A). CysAP (Figure 4B) activity was not modified either in soluble or membrane-bound fractions in renal medulla of NMU-treated rats with or without mammary tumors. On the contrary, we found a highly significant increase $(\mathrm{P}<0.001)$ by $357 \%$ in PAP activity in soluble fraction of rats with NMU-induced mammary tumors when compared with the control group or NMUtreated rats without tumors (Figure 4C). However, no changes were found in PAP activity in membrane-bound fraction of renal medulla.

Regarding plasma and urine chemistry measurements, Tables 1 and 2 show plasma and urine levels of electrolytes, non-protein nitrogenous compounds, albumin and total protein in control animals and animals treated with NMU that developed or not mammary tumors. No significant changes were found in plasma calcium, phosphorus, sodium, potassium, chloride, urea, creatinine or uric acid levels. On the contrary, slightly significant $(\mathrm{P}>0.05)$ decreased levels of albumin by $17 \%$ and total protein by $15.6 \%$ were found in animals with mammary tumors when compared with the control group or with NMU-treated rats without tumors (Table 1). Finally, no significant changes were found in urine calcium, phosphorus, sodium, potassium, chloride, urea, creatinine or uric acid levels. On the contrary, significant ( $P>0.01$ ) increased levels of albumin by $134 \%$ and total protein by 98 $\%$ were found in animals with mammary tumors when compared with the control group or with NMU-treated rats without tumors (Table 2).

\section{Discussion}

To our knowledge, the present work describes for the first time in the literature changes in renal aminopeptidase specific activities promoted by breast cancer, using an animal model induced by NMU. Breast cancer induced in rat by NMU is used for the study of mammary carcinogenesis because it closely mimics human breast disease [39]. NMU-induced tumors are exclusively localised in the mammary gland, are hormone-dependent, highly aggresive, transplantable and show metastasis to other organs [40]. Our results show changes in proteolytic regulatory enzymes involved in several peptide hormones regulation in both renal cortex and medulla. However, little signs of renal failure appears, with a slight plasma hypoalbuminemia and hypoproteinemia, but without changes in the plasma levels of electrolytes (sodium, potassium, calcium, chloride or phosphorous) or non-protein nitrogenous compounds (urea, creatinine or uric acid). In the same way, in urine, certain proteinurie and albuminurie were found, whereas no differences were found in electrolytes and nonprotein nitrogenous compounds. Therefore, the changes found in renal aminopeptidase specific activities could be considered as parallel effects to breast cancer development in the specific functions regulated by these enzymes, and/or early clues of subsequent processes related to renal damage that could occur in the more advanced stages of the disease.

Regarding the proteolityc regulatory enzymes of the RAAS, we have not found differences either in ASAP, APA, APN, APB or IRAP specific activities in renal cortex, but significant increases were found in soluble ASAP and membrane-bound IRAP in renal medulla. However, we have not found changes in the electrolytic balance, which support the idea that other functions not related to the electrolytic homeostasis could be altered. In this way, it has been recently described that Chloride channel ClC-5 binds to ASAP to regulate renal albumin endocytosis [41]. ClC-5 is a chloride/proton exchanger that plays an obligate role in albumin uptake by the renal proximal tubule that forms an endocytic 


\section{Renal Medulla}

\section{Aminopeptidase $\mathrm{N}$}

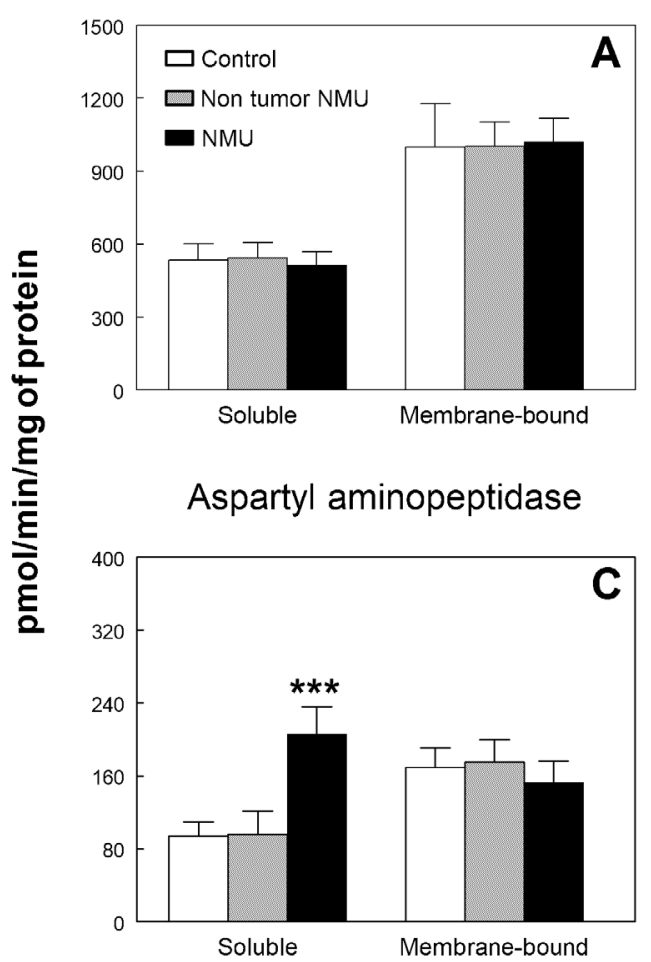

Aminopeptidase B

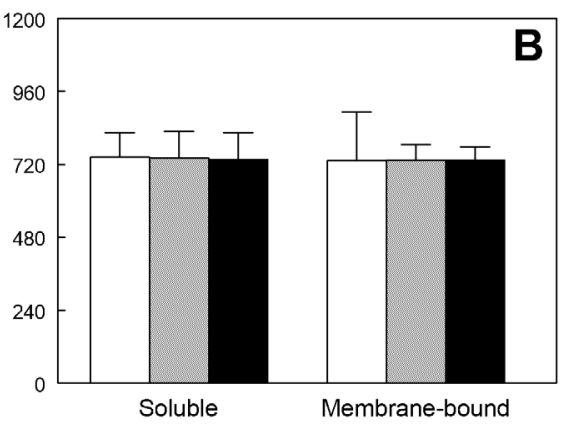

Aminopeptidase A

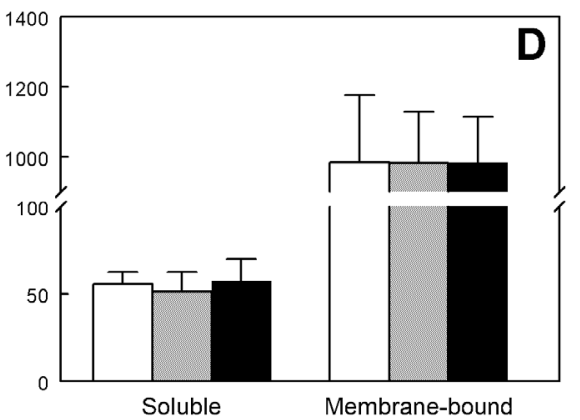

Figure 3. Soluble and membrane bound (A) aminopeptidase N, (B) aminopeptidase B, (C) aspartyl aminopeptidase and (D) aminopeptidase A specific activities in renal medulla of control animals and animals treated with N-methyl-N-nitrosourea (NMU) which developed or not mammary tumors. Results are expressed as picomoles of the corresponding aminoacylß-naphthylamide hydrolyzed per min and per mg of protein (Mean $\pm \mathrm{SEM} ; \mathrm{P}<0.001$ ).

Table 1. Plasma levels of electrolytes, non-protein nitrogenous compounds and albumin in control animals and animals treated with N-methyl-N-nitrosourea (NMU) that developed or not mammary tumors.

\begin{tabular}{|c|c|c|c|c|}
\hline Parameter & Control & Non-tumor NMU & NMU & Significance level \\
\hline $\begin{array}{c}\text { Calcium }(\mathrm{mg} / \mathrm{dL}) \\
\text { Phosphorus }(\mathrm{mg} / \mathrm{dL}) \\
\text { Sodium }(\mathrm{mEq} / \mathrm{L}) \\
\text { Potassium }(\mathrm{mEq} / \mathrm{L}) \\
\text { Chloride }(\mathrm{mEq} / \mathrm{L})\end{array}$ & $\begin{array}{c}10.77 \pm 0.10 \\
5.0 \pm 0.35 \\
140.75 \pm 0.59 \\
5.26 \pm 0.18 \\
99.38 \pm 0.59\end{array}$ & $\begin{array}{c}10.75 \pm 0.20 \\
4.75 \pm 0.34 \\
141.00 \pm 1.35 \\
4.62 \pm 0.19 \\
100.75 \pm 0.75\end{array}$ & $\begin{array}{c}10.65 \pm 0.26 \\
5.07 \pm 0.77 \\
140.75 \pm 0.85 \\
4.65 \pm 0.23 \\
101.25 \pm 0.47\end{array}$ & $\begin{array}{l}\text { n.s. } \\
\text { n.s. } \\
\text { n.s. } \\
\text { n.s. } \\
\text { n.s. }\end{array}$ \\
\hline $\begin{array}{c}\text { Urea }(\mathrm{mg} / \mathrm{dL}) \\
\text { Creatinine }(\mathrm{mg} / \mathrm{dL}) \\
\text { Uric acid }(\mathrm{mg} / \mathrm{dL})\end{array}$ & $\begin{array}{c}48.13 \pm 2.07 \\
0.67 \pm 0.025 \\
1.23 \pm 0.15\end{array}$ & $\begin{array}{l}45.75 \pm 2.62 \\
0.65 \pm 0.028 \\
1.15 \pm 0.086\end{array}$ & $\begin{array}{c}49.00 \pm 4.37 \\
0.65 \pm 0.028 \\
1.60 \pm 0.23\end{array}$ & $\begin{array}{l}\text { n.s. } \\
\text { n.s. } \\
\text { n.s. }\end{array}$ \\
\hline $\begin{array}{c}\text { Albumin }(\mathrm{g} / \mathrm{dL}) \\
\text { Total protein }(\mathrm{g} / \mathrm{dL})\end{array}$ & $\begin{array}{c}3.65 \pm 0.078 \\
7.08 \pm 0.23\end{array}$ & $\begin{array}{l}3.58 \pm 0.19 \\
7.16 \pm 0.12\end{array}$ & $\begin{array}{l}2.97 \pm 0.36^{\mathrm{a}} \\
6.01 \pm 0.20^{\mathrm{a}}\end{array}$ & $\begin{array}{l}{ }^{a} \mathbf{P}<0.05 \\
{ }^{a} \mathrm{P}<0.05\end{array}$ \\
\hline
\end{tabular}

Table 2. Urine levels of electrolytes, non-protein nitrogenous compounds and albumin in control animals and animals treated with N-methyl-N-nitrosourea (NMU) that developed or not mammary tumors.

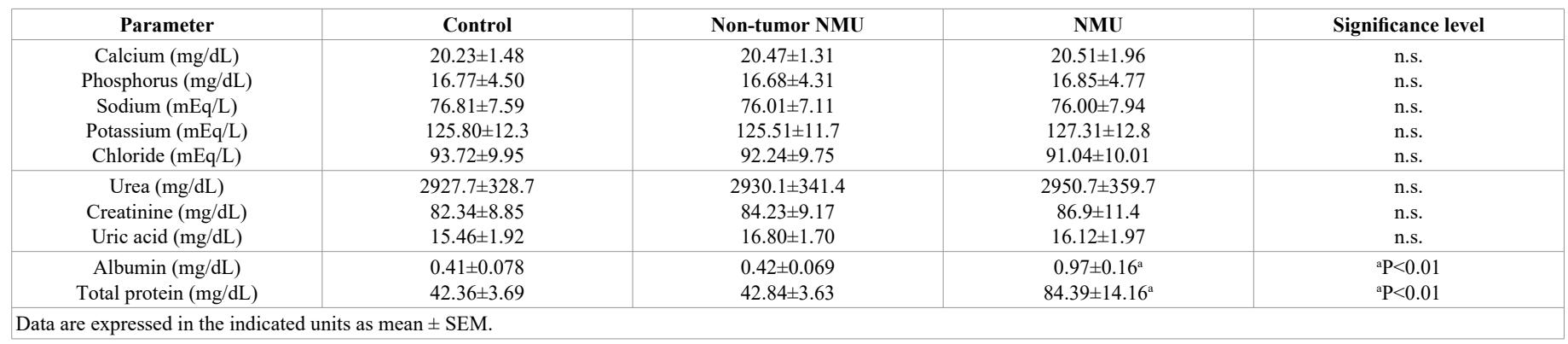




\section{Renal Medulla}

\section{Insulin-regulated aminopeptidase}

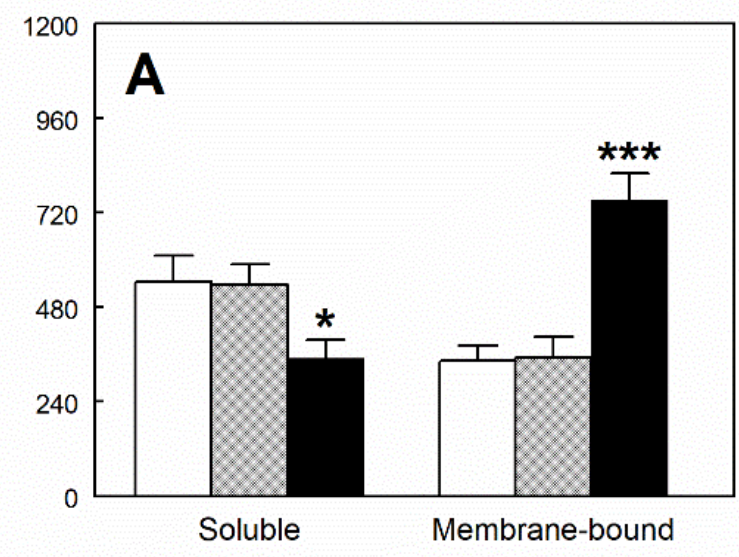

Oxytocinase

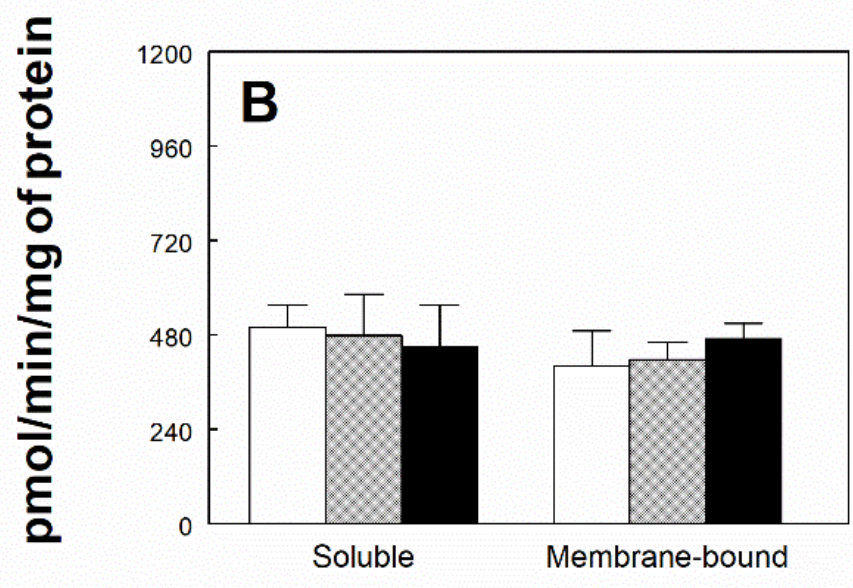

\section{Pyroglutamyl aminopeptidase}

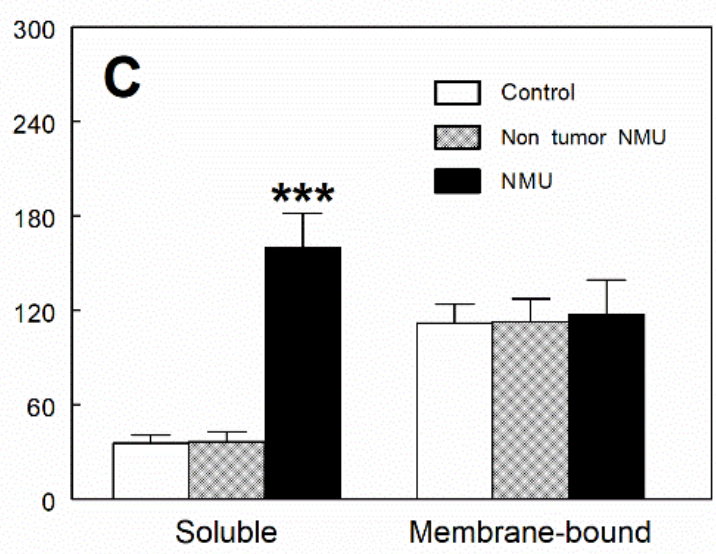

Figure 4. Soluble and membrane bound (A) insulin-regulated aminopeptidase, (B) cystinyl aminopeptidase and (C) pyroglutamyl aminopeptidase specific activities in renal medulla of control animals and animals treated with N-methyl-N-nitrosourea (NMU) which developed or not mammary tumors. Results are expressed as picomoles of the corresponding aminoacyl- $\beta$-naphthylamide hydrolyzed per min and per $\mathrm{mg}$ of protein (Mean $\pm \mathrm{SEM}$; $* \mathrm{P}<0.05 ; * * * \mathrm{P}<0.001)$. complex with the albumin receptor megalin/cubilin which has ASAP as binding partner, being the two proteins bound directly to each other. Overexpression of wild-type ASAP increased cell-surface levels of ClC-5 and albumin uptake [41]. Due to the physiological role of ASAP remains largely unresolved, the changes found here showing increased ASAP specific activity could be related with the hypoalbuminemia found in animals with mammary tumors and indicate a response mechanism from kidney to avoid the loss of albumin. However, it has been also described a role for ASAP in cytoskeletal maintenance related to endocytosis of albumin in kidney cells that must be also taken into account.

Regarding IRAP specific activity, it has been proposed that in renal cortex this enzyme together with the other peptidases present in the brush border of the proximal tubules are involved in the generation of free amino acids for reabsorption $[42,43]$. However, in the inner medulla, IRAP enzyme appears in the principal cells of the collecting duct and in interstitial cells. In the principal cells of the collecting duct, vasopressin (a substrate of IRAP) induces the translocation of the vasopressin responsive water channel aquaporin-2 from specialized vesicles to the apical membrane [44]. Therefore, our results may also indicate an alteration in water reabsortion through the modulation of vasopressin functions. However, water movements are not reflected in plasma electrolyte levels. It must be also considered that IRAP has been also described as leucyl aminopeptidase, which has been shown as a sensitive indicator of early renal damage $[45,46]$. Therefore, the increase found in animals with breast cancer could also be an early sign of the renal damage that could occur in the more advanced stages of the disease.

Regarding PAP activity, we have observed a significant decrease in renal cortex and a significant increase in renal medulla, both in the soluble fraction, whereas no changes were observed in the membranebound fraction either in renal cortex or medulla. In this sense, inmunohistochemical studies in rats have also demonstrated a PAP localization specifically in the renal proximal convoluted tubules, lesser in the distal tubules and that was not present in renal glomeruli [33].

The precise mechanism of action and functional roles for PAP in kidney remains unclear. It is thought that PAP modulates the activity of peptide local factors and their access to adjacent cells by converting pro-peptides to their active forms or inactivating them. Moreover, accumulating data suggest that peptidase activity on bioactive peptides converts these active molecules into fragments with retained but modified biological effects [47]. Not only do changes in peptidase activities reflect tissue damage in cancer, but also the functional status of their peptide substrates, due to their involvement in the control of these local factors that act through intracrine, autocrine, or paracrine mechanisms [1]. In fact, evidence has accumulated in favor of the intracellular trafficking and action of certain peptide hormones and proteolytic enzymes, known as intracrine action. Peptides degraded by PAP are included among those reported to have intracrine action. Intracrine functionality can serve to link trophic events with ribosomal regulation, and growth regulation with ribosomal synthesis. Cell proliferation or differentiation in a great variety of tissues, are influenced by the intracrine action of peptides and peptidases [48]. The changes in the activity of soluble PAP in kidney found here is compatible with the idea that a relevant action of this enzyme activity during breast cancer development may be intracrine, acting within the cell. In this way, GnRH and TRH are the main peptides processed by PAP, and both peptides have been described to have certain functions in peripheral tissues including the kidney [30]. Thus, it has been described in renal tissue GnRH receptors [30] and GnRH mRNA expression [49] which 
suggest that both elements have functional roles in the regulation of the cellular functions in an intracrine, autocrine or paracrine way, besides its regulatory function in the secretion of pituitary gonadotrophins.

It is also well known the direct effects of TRH on renal function, promoting a significant reduction in salt and water outputs, glomerular filtration rate and renal plasma flow [50]. However, to our knowledge, little information is available about renal TRH or TRH-like peptides, the distribution of TRH receptors in kidney [51], their functions or mechanisms of action. Therefore, changes found in PAP activity could also be related with the regulation of these processes.

Other peptides susceptible to be regulated by PAP are bombesinlike peptides. These peptides have been related to the maintaining of renal function promoting a potent antidiuretic effect, and have been also related with several type of cancers [52]. In the same way, gastrin releasing peptide (GRP), the mammalian homolog of bombesin, has been described as an autocrine or endocrine growth factor in a wide range of cancers, including carcinoma of breast, prostate and colon [52]. More recently, Dumesny et al. have described the presence in rat kidney of GRP mRNA and peptide, and the expression of the two mayor GRP receptor subtypes, suggesting that GRP can also be an autocrine/intracrine regulatory factor in the kidney associated to several renal function and dysfunctions [53].

Finally, the changes observed in PAP activity could also reflect an early renal damage promoted by the development of the disease. In fact, Balupuri, et al. have proposed PAP activity, besides LeuAP (IRAP) activity, as a putative marker of renal damage [36].

\section{Conclusions}

Our results demonstrate that animals with breast cancer induced by NMU administration show changes in several renal functions regulated by proteolytic regulatory enzymes such as those involved in RAAS, GnRH, TRH, among other peptide metabolism. The mechanisms by which breast cancer promotes renal damage remains unknown and needs further research, but this allows us to suggest that the damage caused by breast cancer in the kidney could make this organ more sensitive to future damage such as the nephrotoxicity induced by the various chemotherapy treatments currently available against cancer, and that the knowledge of the mechanisms by which breast cancer causes this initial damage in the kidney could allow the development of new strategies that avoid the nephrotoxicity of antitumor drugs.

\section{Acknowledgments}

Supported by Junta de Andalucía through PAIDI CTS-1039.

\section{References}

1. Martinez JM, Prieto I, Ramirez MJ, Cueva C, Alba F, et al. (1999) Aminopeptidase activities in breast cancer tissue. Clin Chem 45: 1797-1802. [Crossref]

2. Carrera-Gonzalez Mdel P, Ramirez-Exposito MJ, Duenas B, Martínez-Ferrol J, DoloresMayas M, et al. (2012) Putative relationship between hormonal status and serum pyrrolidone carboxypeptidase activity in pre- and post- menopausal women with breast cancer. Breast 21: 751-754.

3. Martinez-Martos JM, del Pilar Carrera-Gonzalez M, Duenas B, Mayas MD, García MJ, et al. (2011) Renin angiotensin system-regulating aminopeptidase activities in serum of pre- and postmenopausal women with breast cancer. Breast 20: 444-447. [Crossref]

4. Ramirez-Exposito MJ, Carrera-Gonzalez Mdel P, Mayas MD, Dueñas B, MartínezFerrol J, et al. (2012) Neoadjuvant chemotherapy modifies serum angiotensinase activities in women with breast cancer. Maturitas 72: 79-83. [Crossref]

5. Carrera Mdel P, Ramirez-Exposito MJ, Valenzuela MT, García MJ, Mayas MD, et al. (2005) Specific enkephalin-degrading aminopeptidase activity in the HPT and HPO axes of rats with breast cancer induced by N-methyl nitrosourea. Regul Pept 124: 157161. [Crossref]
6. Carrera MP, Ramirez-Exposito MJ, Valenzuela MT, Dueñas B, García MJ, et al. (2005) Serum enkephalin-degrading aminopeptidase activity in N-methyl nitrosourea-induced rat breast cancer. Anticancer Res 25: 193-196. [Crossref]

7. Carrera MP, Ramirez-Exposito MJ, Valenzuela MT, García MJ, Mayas MD, et al. (2005) Pyrrolidon carboxypeptidase activities in the hypothalamus-pituitary-thyroid and hypothalamus-pituitary-ovary axes of rats with mammary gland cancer induced by N-methyl nitrosourea. Horm Metab Res 37: 74-78. [Crossref]

8. Carrera MP, Ramirez-Exposito MJ, Valenzuela MT, García MJ, Mayas MD, et al. (2004) Glutamyl- but not aspartyl-aminopeptidase activity is modified in serum of N-methyl nitrosourea-induced rat mammary tumours. Anticancer Res 24: 801-805. [Crossref]

9. Carrera MP, Ramirez-Exposito MJ, Valenzuela MT, García MJ, Mayas MD, et al. (2003) Serum pyrrolidone carboxypeptidase activity in N-methyl-nitrosourea induced rat breast cancer. Horm Metab Res 35: 502-505. [Crossref]

10. Carrera MP, Ramirez-Exposito MJ, Valenzuela MT, García MJ, Mayas MD, et al. (2004) Serum oxytocinase activity is related to tumor growth parameters in N-methyl nitrosourea induced rat breast cancer. Life Sci 75: 1369-1377. [Crossref]

11. Carrera MP, Ramirez-Exposito MJ, Valenzuela MT, Dueñas B, García MJ, et al. (2006) Renin-angiotensin system-regulating aminopeptidase activities are modified in the pineal gland of rats with breast cancer induced by N-methyl-nitrosourea. Cancer Invest 24: 149-153. [Crossref]

12. Del Pilar Carrera M, Ramirez-Exposito MJ, Garcia MJ, Mayas MD, Martínez-Martos JM (2009) Ovarian renin--angiotensin system-regulating aminopeptidases are involved in progesterone overproduction in rats with mammary tumours induced by $\mathrm{N}$-methyl nitrosourea. Anticancer Res 29: 4633-4637. [Crossref]

13. Carrera-Gonzalez MP, Ramirez-Exposito MJ, de Saavedra JM, Sánchez-Agesta $\mathrm{R}$, Mayas MD, et al. (2011) Hypothalamus-pituitary-thyroid axis disruption in rats with breast cancer is related to an altered endogenous oxytocin/insulin-regulated aminopeptidase (IRAP) system. Tumour Biol 32: 543-549. [Crossref]

14. Carrera-Gonzalez MP, Ramirez-Exposito MJ, Mayas MD, García MJ, Martínez-Martos JM (2013) Local thyroid renin-angiotensin system in experimental breast cancer. Life Sci 93: 1004-1009. [Crossref]

15. Siragy HM (2006) Angiotensin II compartmentalization within the kidney: effects of salt diet and blood pressure alterations. Curr Opin Nephrol Hypertens 15: 50-53. [Crossref]

16. Remuzzi G, Perico N, Macia M, Ruggenenti P (2005) The role of renin-angiotensinaldosterone system in the progression of chronic kidney disease. Kidney Int Suppl 99: S57-S65. [Crossref]

17. Chansel D, Ardaillou R (1998) Active metabolites derived from angiotensin II. Nephrologie 19: 427-432. [Crossref]

18. Ramirez-Exposito MJ, Martinez JM, Prieto I, Alba F, Ramírez M (2000) Comparative distribution of glutamyl and aspartyl aminopeptidase activities in mouse organs. Horm Metab Res 32: 161-163. [Crossref]

19. Kambayashi Y, Bardhan S, Takahashi K, Tsuzuki S, Inui H, et al. (1993) Molecular cloning of a novel angiotensin II receptor isoform involved in phosphotyrosine phosphatase inhibition. J Biol Chem 268: 24543-24546. [Crossref]

20. Mukoyama M, Nakajima M, Horiuchi M, Sasamura H, Pratt RE, et al. (1993) Expression cloning of type 2 angiotensin II receptor reveals a unique class of seventransmembrane receptors. $J$ Biol Chem 268: 24539-24542. [Crossref]

21. Stegbauer J, Coffman TM (2011) New insights into angiotensin receptor actions: from blood pressure to aging. Curr Opin Nephrol Hypertens 20: 84-88. [Crossref]

22. Wright JW, Harding JW (2013) The brain renin-angiotensin system: a diversity of functions and implications for CNS diseases. Pflugers Arch 465: 133-151. [Crossref]

23. Johnston CI (1990) ACE inhibitors and the kidney. Nephron 55: 1-2.

24. Blair-West JR, Coghlan JP, Denton DA, Funder JW, Scoggins BA, et al. (1971) The effect of the heptapeptide (2-8) and hexapeptide (3-8) fragments of angiotensin II on aldosterone secretion. J Clin Endocrinol Metab 32: 575-578. [Crossref]

25. Matsumoto H, Nagasaka T, Hattori A, Rogi T, Tsuruoka N, et al. (2001) Expression of placental leucine aminopeptidase/oxytocinase in neuronal cells and its action on neuronal peptides. Eur J Biochem 268: 3259-3266. [Crossref]

26. Tsujimoto M, Hattori A (2005) The oxytocinase subfamily of M1 aminopeptidases. Biochim Biophys Acta 1751: 9-18. [Crossref]

27. Tobin VA, Arechaga G, Brunton PJ, Russell JA, Leng G, et al. (2014) Oxytocinase in the female rat hypothalamus: a novel mechanism controlling oxytocin neurones during lactation. J Neuroendocrinol 26: 205-216. [Crossref] 
28. Nagasaka T, Nomura S, Okamura M, Tsujimoto M, Nakazato H, et al. (1997) Immunohistochemical localization of placental leucine aminopeptidase/oxytocinase in normal human placental, fetal and adult tissues. Reprod Fertil Dev 9: 747-753. [Crossref]

29. Mizutani S, Safwat MA, Goto K, Tsujimoto M, Nakazato H, et al. (1995) Initiating and responsible enzyme of arginine vasopressin degradation in human placenta and pregnancy serum. Regul Pept 59: 371-378. [Crossref]

30. Sion-Vardi N, Kaneti J, Segal-Abramson T, Giat J, Levy J, et al. (1992) Gonadotropinreleasing hormone specific binding sites in normal and malignant renal tissue. $J$ Urol 148: $1568-1570$

31. Heber D, Marshall JC, Odell WD (1978) GnRH membrane binding: identification, specificity, and quantification in nonpituitary tissues. Am J Physiol 235: E227-E230. [Crossref]

32. Iglesias P, Bajo MA, Selgas R, Díez JJ (2017) Thyroid dysfunction and kidney disease: An update. Rev Endocr Metab Disord 18: 131-144. [Crossref]

33. Abe K, Fukuda K, Tokui T (2004) Marginal involvement of pyroglutamyl aminopeptidase I in metabolism of thyrotropin-releasing hormone in rat brain. Biol Pharm Bull 27: 1197-1201. [Crossref]

34. Albiston AL, Ye S, Chai SY (2004) Membrane bound members of the M1 family: more than aminopeptidases. Protein Pept Lett 11: 491-500. [Crossref]

35. Cummins PM, O'Connor B (1996) Bovine brain pyroglutamyl aminopeptidase (type1): purification and characterisation of a neuropeptide-inactivating peptidase. Int $J$ Biochem Cell Biol 28: 883-893. [Crossref]

36. Balupuri S, Talbot D, El-Sheikh M, Snowden C, Manas DM, et al. (2000) Comparison of proteolytic enzymes and glutathione S-transferase levels in non-heart-beating donors' (NHBD) kidney perfusates. Clin Chem Lab Med 38: 1099-1102. [Crossref]

37. Umezawa H (1980) Screening of small molecular microbial products modulating immune responses and bestatin. Recent Results Cancer Res 75: 115-125. [Crossref]

38. Illan-Cabeza NA, Garcia-Garcia AR, Martinez-Martos JM, Ramírez-Expósito MJ, Peña-Ruiz T, et al. (2013) A potential antitumor agent, (6-amino-1-methyl5-nitrosouracilato-N3)-triphenylphosphine-gold(I): structural studies and in vivo biological effects against experimental glioma. Eur J Med Chem 64: 260-272. [Crossref]

39. Chan MM, Lu X, Merchant FM, Iglehart JD, Miron PL (2005) Gene expression profiling of NMU-induced rat mammary tumors: cross species comparison with human breast cancer. Carcinogenesis 26: 1343-1353. [Crossref]

40. Rivera ES, Andrade N, Martin G, Melito G, Cricco G, et al. (1994) Induction of mammary tumors in rat by intraperitoneal injection of NMU: histopathology and estral cycle influence. Cancer Lett 86: 223-228. [Crossref]
41. Lee A, Slattery C, Nikolic-Paterson DJ, Hryciw DH, Wilk S, et al. (2015) Chloride channel ClC-5 binds to aspartyl aminopeptidase to regulate renal albumin endocytosis. Am J Physiol Renal Physiol 308: F784-F792. [Crossref]

42. Albiston AL, Yeatman HR, Pham V, Fuller SJ, Diwakarla S, et al. (2011) Distinct distribution of GLUT4 and insulin regulated aminopeptidase in the mouse kidney. Regul Pept 166: 83-89. [Crossref]

43. Albiston AL, Peck GR, Yeatman HR, Fernando R, Ye S, et al. (2007) Therapeutic targeting of insulin-regulated aminopeptidase: heads and tails? Pharmacol Ther 116: 417-427. [Crossref]

44. Nielsen S, Chou CL, Marples D, Christensen EI, Kishore BK, et al. (1995) Vasopressin increases water permeability of kidney collecting duct by inducing translocation of aquaporin-CD water channels to plasma membrane. Proc Natl Acad Sci U S A 92: 1013-1017. [Crossref]

45. Bedir A, Ozener IC, Emerk K (1996) Urinary leucine aminopeptidase is a more sensitive indicator of early renal damage in non-insulin-dependent diabetics than microalbuminuria. Nephron 74: 110-113. [Crossref]

46. Awad H, el-Safty I, Abdel-Gawad M, el-Said S (2003) Glomerular and tubular dysfunction in children with congenital cyanotic heart disease: effect of palliative surgery. Am J Med Sci 325: 110-114. [Crossref]

47. Varona A, Blanco L, Lopez JI, Gil J, Agirregoitia E, et al. (2007) Altered levels of acid, basic, and neutral peptidase activity and expression in human clear cell renal cell carcinoma. Am J Physiol Renal Physiol 292: F780-F788. [Crossref]

48. Agirregoitia N, Casis L, Gil J, Ruiz F, Irazusta J (2007) Ontogeny of prolyl endopeptidase and pyroglutamyl peptidase I in rat tissues. Regul Pept 139: 52-58. [Crossref]

49. Kakar SS, Jennes L (1995) Expression of gonadotropin-releasing hormone and gonadotropin-releasing hormone receptor mRNAs in various non-reproductive human tissues. Cancer Lett 98: 57-62. [Crossref]

50. Garland HO (1987) Effects of thyrotrophin-releasing hormone on renal function in the rat. $J$ Endocrinol 113: 445-448. [Crossref]

51. Hokfelt T, Tsuruo Y, Ulfhake B, Cullheim S, Arvidsson U, et al. (1989) Distribution of TRH-like immunoreactivity with special reference to coexistence with other neuroactive compounds. Ann N Y Acad Sci 553:76-105. [Crossref]

52. Preston SR, Miller GV, Primrose JN (1996) Bombesin-like peptides and cancer. Crit Rev Oncol Hematol 23: 225-238. [Crossref]

53. Dumesny C, Whitley JC, Baldwin GS, Giraud AS, Shulkes A (2004) Developmental expression and biological activity of gastrin-releasing peptide and its receptors in the kidney. Am J Physiol Renal Physiol 287: F578-F585. [Crossref]

Copyright: (C2018 Martínez-Martos JM. This is an open-access article distributed under the terms of the Creative Commons Attribution License, which permits unrestricted use, distribution, and reproduction in any medium, provided the original author and source are credited. 